\title{
INFECTIOUS HEPATITIS COMPLICATED BY SECONDARY INVASION WITH SALMONELLA ${ }^{1}$
}

\author{
By W. P. HAVENS, JR.,2 AND HERBERT A. WENNER \\ (From the Section of Preventive Medicine, Yale University School of Medicine, New Haven)
}

(Received for publication June 25, 1945)

Information has been obtained from the experimental transmission of infectious hepatitis to human volunteers ( 1 to 7$)$ to indicate that the icterogenic agent, which is known to be in the blood and stools of patients during active stages of the disease, is filtrable and may be transmitted to human volunteers by feeding or by parenteral inoculation of infectious material.

Although the exact nature of this icterogenic agent is not yet defined, it is believed to be a virus $(6,7)$. These facts are in agreement with the failure to identify any specific bacterial organism consistently with this disease (8 to 11 ).

In view of this recent knowledge, the purpose of this paper is: (1) to point out the extensive and controversial experience of World War I in which the frequent association of infectious hepatitis and certain strains of salmonellae was observed; (2) to report in detail the occurrence of secondary invasion with $S$. choleraesuis in 2 human volunteers with experimental virus-induced hepatitis. We believe that this finding, limited as it is to a small number of patients, points the way to an explanation of the controversy over the etiology of this disease which existed 25 years ago.

\section{HISTORICAL}

During World War I, the frequent isolation of certain strains of salmonellae from patients with infectious hepatitis was observed. This occurred in occasional family outbreaks (12) and small institutional (13) and civilian $(14,15)$ epidemics, but the preponderant evidence was obtained from the armed forces. In Roumanian (16), French (17), and British (18) troops, more particularly in the Dardanelles and Mesopotamia, outbreaks of infectious hepatitis occurred closely following or

1 These investigations were aided in part by the Commission on Neurotropic Virus Diseases, Board for the Investigation and Control of Influenza and Other Epidemic Diseases in the Army, Preventive Medicine Service, Office of The Surgeon General, United States Army. 2 Major, M.C., A.U.S. coincident with epidemics of febrile gastroenteritis and with large numbers of infections due to various strains of salmonellae. A concomitant increase in incidence of typhoid was often observed. Characteristically, these epidemics were prevalent among troops which had been exposed to great hardship and whose sanitary conditions were poor.

During investigations on such outbreaks of infectious hepatitis, organisms of the paratyphoid group were frequently recovered from the blood, stools, or bile of patients with jaundice $(12,14$ to 17). Numerous strains were identified but because of atypical cultural and serological characteristics they were considered as variant forms. It was suggested that such atypical strains of the paratyphoid group (usually $S$. schottmuelleri) acquired new characteristics during epidemics-taking on an icterogenic capacity. As such they were considered to be the etiologic agents of infectious hepatitis, the jaundice being distinguished from the icterus occurring occasionally in the course of typhoid or paratyphoid fever. The sera of these patients frequently showed the development of agglutinins for various strains of salmonellae (15 to 17).

A study (17) was made of an epidemic of febrile gastroenteritis in the French Army during the 8 months' campaign in the Dardanelles. Early in the campaign, the rate of typhoid and paratyphoid fever was high, and the organisms isolated were classical in cultural characteristics and agglutination reactions. As the gastro-enteritis declined, cases of jaundice appeared. From these jaundiced patients, 94 strains of $S$. paratyphi and $S$. schottmuelleri were recovered, but a change in bacteriologic characteristics was noted in atypical cultural reactions and failure to agglutinate specific sera, although there was strong homologous agglutination with the serum of the patients.

There was an epidemic of jaundice among troops in the Roumanian Army in which approxi- 
mately 1 month after a large outbreak of nonspecific gastroenteritis, cases of jaundice began to appear. Fourteen strains of $S$. schottmuelleri were isolated from jaundiced patients. Of 90 patients with jaundice, the sera of all but 3 agglutinated at least 1 of these strains ( $S$. schottmuelleri) in a titre as high as $1: 300$.

In contrast to the etiological interpretation of the association of salmonellae with infectious hepatitis were the views of others, including British (19 to 21), German (22), French $(23,24)$, and Egyptian (25) investigators, who studied similar epidemics among troops and civilian populations at this time and later. The general experience in this group was the failure to identify consistently any bacterial organism with infectious hepatitis. Salmonellae were not encountered in any significant number of patients with jaundice and no serologic relationship between such patients and various strains of salmonellae was observed. It was also pointed out that a small percentage of patients with paratyphoid fever had jaundice as a complication. However, it was suggested that where jaundice and paratyphoid fever appeared together in large numbers of patients, they constituted double infections. This was based on the theory that the method of transmission of the 2 diseases might be the same: viz., the intestinal-oral route, so that unsanitary conditions conducive to the spread of paratyphoid fever would also favor the spread of infectious hepatitis. This is significant in view of the present information on the manner of experimental transmission of infectious hepatitis. Certain clinical differences were also described at that time, in that the course of disease of the patient with an alleged double infection (paratyphoid fever and infectious hepatitis) was more severe with prolonged fever, while that of the patient with infectious hepatitis alone was usually milder with less fever.

\section{TRANSMISSION EXPERIMENTS}

During the past year, experiments in the transmission of infectious hepatitis have been conducted by the Neurotropic Virus Commission of the U. S. Army. Forty-nine human volunteers have been inoculated or fed with material either known or sispected to contain an agent of infectious hepatitis $(4,7,26,27)$. Of these, 20 have contracted

the disease. Eight additional men were given an agent of homologous serum jaundice, and of these 3 contracted the disease (4).

It was mentioned in an earlier communication (4) that in 1 of these experiments in the transmission of hepatitis to human volunteers, 2 patients had developed bacteremia with $S$. choleraesuis during the acute phase of their hepatitis. Details of this finding and its interpretation were not given.

This experiment was conducted at an institution for mental diseases. Conscientious objectors, assigned there to work in various capacities, volunteered as subjects. Eleven men in all were used, divided into 3 groups of 3 men each with 2 men serving as uninfected controls. (See Figure 1.)

The sources of the infectious materials which these men received are described in Table $I$. They were obtained in 1943 from American and British soldiers in Africa and Sicily. Sera and fresh stools were kept at dry-ice box temperature for 8 months; dehydrated filtrates of urine and stool extracts at room temperature. or ice box temperature for 4 months. Sera and dried filtrates were sterile on culture before use. Stool B contained no pathogenic bacteria.

TABLE I

Source of material

Material

Serum number $3^{*}$

Serum number $4^{*}$

Serum number $5^{*}$

Serum number $6^{*}$

Serum number 7

Stool B

Dehydrated filtrates

of stool and urine extracts V.R.t

* Sera numbers 3 to 6 were second human passage material from a pool of sera obtained from 11 men in the first 24 hours of sandfy fever. There was no previous history of jaundice. Ten were followed for 4 months and did not develop jaundice. The eleventh could not be traced. This pool was prepared by Lt. Col. A. B. Sabin, M.C., and was described in studies reported by Paul et al. as containing an icterogenic agent of homologous serum jaundice (28). From coincident and subsequent work (27) it is our belief that Serum Number 7 was responsible for the hepatitis in Group I." (See Figure 1).

† These filtrates were prepared and dried by Maj. C. $E$. $\operatorname{van}$ Rooyen, R.A.M.C., from patients in various stages of infectious hepatitis at the Fifteenth Scottish Hospital, Middle East Forces.

Note: $(-)$ indicates days before onset of icterus. $(+)$ indicates days after the onset of jaundice. 


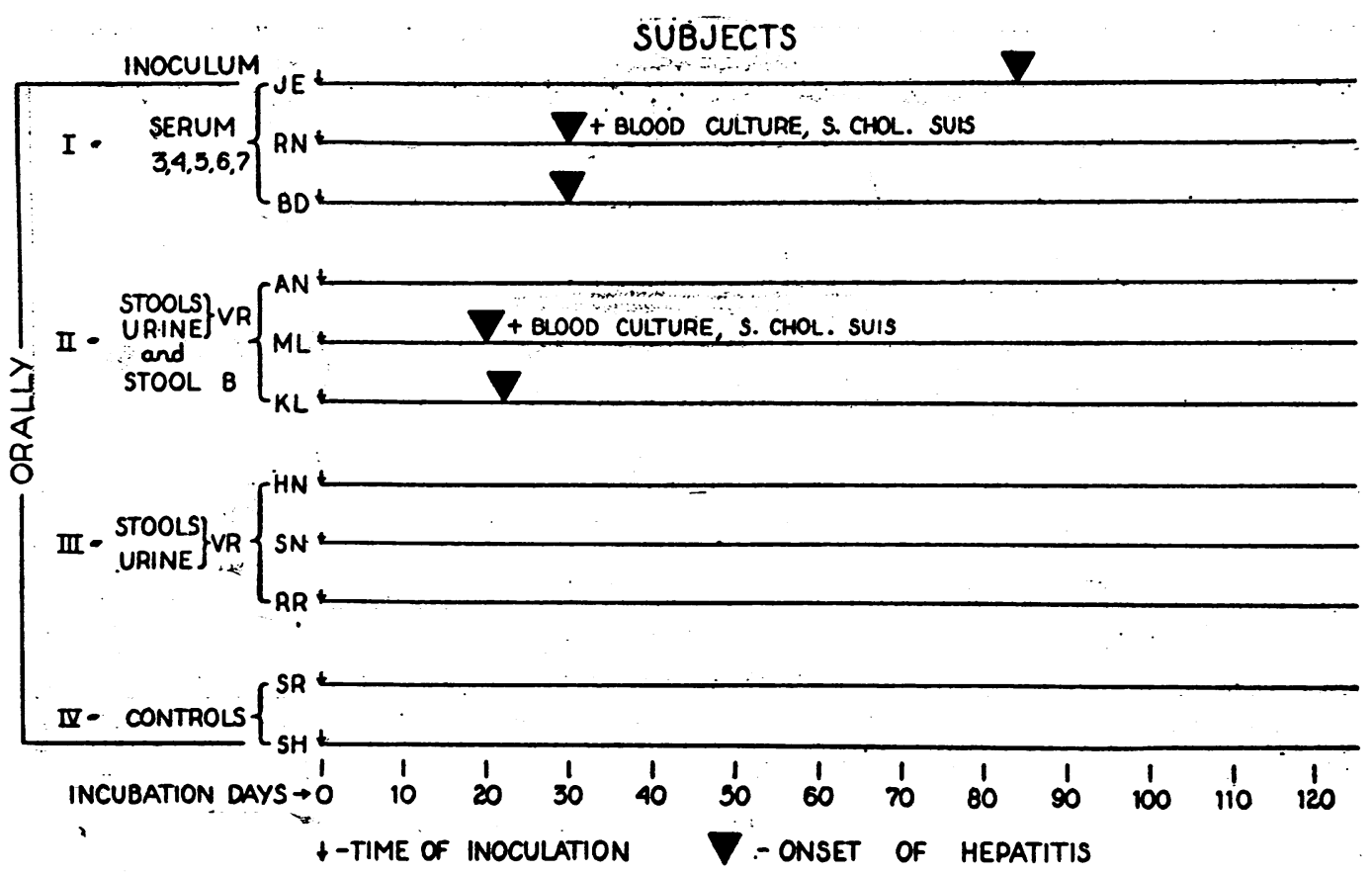

Fig. 1. Itlustration of Results of Ferding Icterogenic Material to a Group of Volunteres

Each subject is represented by a horizontal line. The inoculum which these patients received is indicated by number in the left hand column of Table I. The superimposed bacteremia which occurred in 2 patients is indicated.

Five out of the 6 volunteers in groups I and II contracted experimental hepatitis with a single case of bacteremia appearing in each group (volunteers $\mathrm{RN}$ and $\mathrm{ML}$ ). The course of disease in 2 of the other volunteers (KL and BD) of groups I and II was more or less similar to that of the 2 who had superimposed bacteremia, although of much less severity in relation to constitutional reaction, duration, length, and intensity of febrile response. The fifth volunteer (JE) to contract experimental hepatitis had a mild case. Cultures of the blood of all 3 patients (KL, BD, and JE) were sterile. A summary of the histories of the 2 volunteers who had bacteremia during virusinduced experimental hepatitis is given below.

In Group I, volunteer RN developed experimental hepatitis 30 days after the ingestion of icterogenic serum (See Figure 2). The chief complaint at onset was discomfort in the right upper quadrant. In the next 2 days, he had anorexia, nausea, and headache, and the discomfort in the right upper quadrant extended into the epigastrium. Physical examination on the third day of disease revealed a fairly well-developed and nourished young white male, acutely and mildly ill. The conjunctivae were injected, and there was faint icterus of the sclerae. The liver and spleen were palpable and tender. Mild tenderness was present in the epigastrium. Temperature 101 ${ }^{\circ}$ F. (rectal). Pulse: 60. Resp.: 20. Laboratory data: The leukocytes numbered 4,300 with 65 per cent polymorphonuclear leukocytes and 35 per cent lymphocytes. The urine contained bilirubin, and the serum bilirubin measured $1.85 \mathrm{mgm}$. per cent. The temperature rose progressively reaching $105.4^{\circ} \mathrm{F}$. (rectal) on the sixth day of disease, was remittent for 3 days, and declined to normal on the tenth day. Culture of the blood revealed 3 colonies per milliliter of $S$. choleraesuis on the fifth day of disease, and daily cultures were positive until the thirteenth day. Clinical jaundice reached a peak on the thirteenth day with a serum bilirubin of $6.7 \mathrm{mgm}$. per cent. The total duration of jaundice was 28 days. Recovery was uneventful, and studies of liver function became normal. Repeated cultures of the stool and urine were negative for pathogenic bacteria.

Fifty-one days after the disappearance of jaundice, this patient had a relapse of hepatitis following an attack of non-specific enterocolitis which was treated with sulfaguanidine. Culture of the blood during this relapse was sterile. The stool contained no pathogenic bacteria. He was jaundiced for 15 days, and complete recovery followed.

In Group II, volunteer ML developed experimental infectious hepatitis 20 days after ingestion of infectious stools. (See Figure 3.) The onset of the disease was abrupt with chills, fever, anorexia, nausea, and headache. Physical examination on the fourth day. of disease re- 


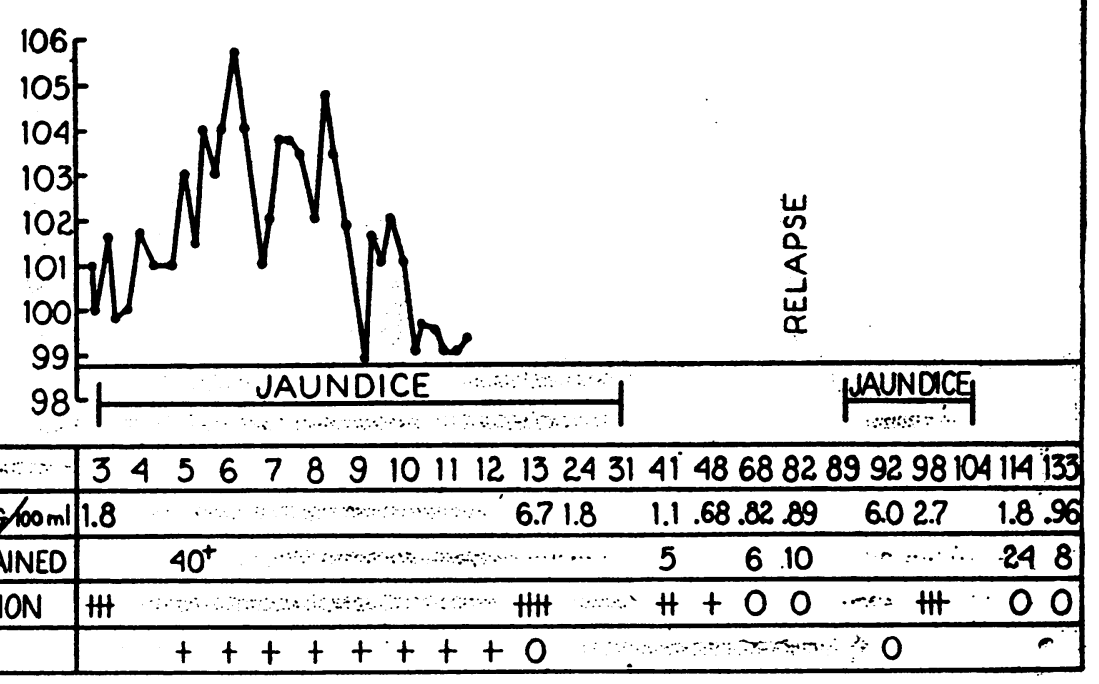

Fig. 2. Clinical Course of Voluntere RN

Rectal temperatures are recorded. Five mgm. of bromsulfalein per kilogram of body weight was injected intravenously, and the percentage retained in the blood was measured after 30 minutes.

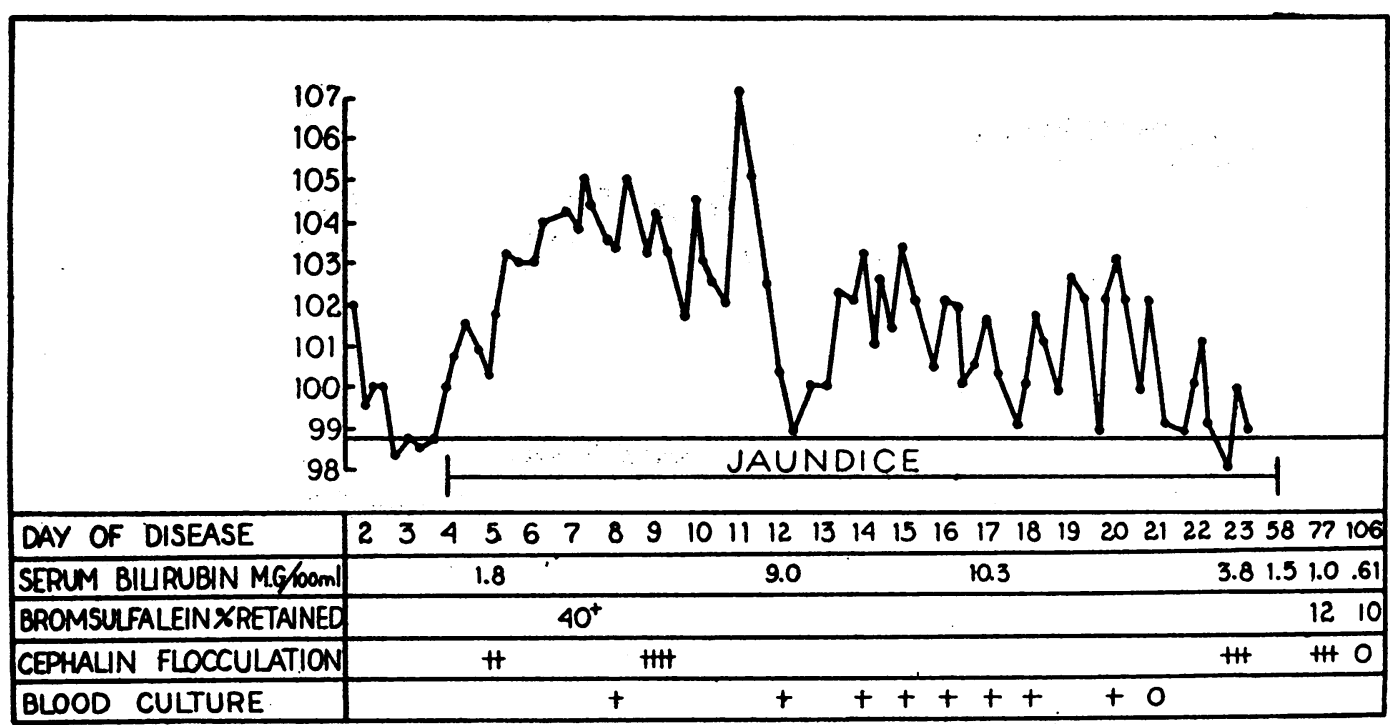

Fig. 3. Clinical Course of Volunteer ML

Rectal temperatures are recorded. Five mgm. of bromsulfalein per kilogram of body weight were injected intravenously, and the percentage retained in the blood was measured after 30 minutes.

vealed an acutely mildly-ill young white male. The conjunctivae were injected, and the sclerae were faintly icteric. There was mild tenderness in the right upper quadrant, and the liver was just palpable. Temperature 101' F.' (rectal). Pulse: 82. Resp.: 22. Laboratory data: The leukocytes numbered 5,350 with 69 per cent polymorphonuclear leukocytes, 27 per cent lymphocytes and 4 per cent monocytes. The serum bilirubin measured $1.51 \mathrm{mgm}$. per cent and the urine was negative for bilirubin. The temperature rose progressively to $105^{\circ} \mathrm{F}$. (rectal) at the end of the first week, ranging from $102^{\circ}$ to as high as $107^{\circ} \mathrm{F}$. (rectal) through the second week, and from $100^{\circ}$ to $103^{\circ} \mathrm{F}$. (rectal) the third week, becoming normal at the beginning of the fourth week. Culture of 
the blood revealed 3 colonies per milliliter of $S$. choleraesuis on the eighth day of disease, and daily cultures remained positive until the 20th day of disease. During the course of illness, both liver and spleen were enlarged and tender. Jaundice reached its peak on the seventeenth day with the serum bilirubin measuring $10.3 \mathrm{mgm}$. per cent. The total duration of jaundice was 54 days. Recovery was uneventful, and liver function studies became normal. Repeated cultures of the stool and urine were negative for pathogenic bacteria.

The exact relationship of the bacteremia caused by these strains of $S$. choleraesuis to the experimental cases of virus-induced infectious hepatitis is not clear. The fact that bacteremia appeared in these experimental cases at one institution, while it failed to occur in any of the several experiments in the transmission of virus-induced infectious hepatitis in other institutions, make it evident that the rôle of the bacteria was subsidiary rather than casual. The presence of $S$. choleraesuis has been regarded by us as a secondary invasion of the 2 subjects already experimentally infected with the filtrable agent of infectious hepatitis. The basis of this interpretation is that in the institution where these men worked and lived, frequent epidemics of bacillary dysentery had occurred; large outbreaks due to Flexner bacilli appeared in 1939 and 1943. Infections of inmates with members of the typhoid-paratyphoid group of organisms had been frequent. A survey of cultures of stools from inmates indicated that there was a considerable focus of infection with various strains of salmonellae at the onset of and during this experiment.

\section{CULTURES OF STOOLS}

Because of the presence of several strains of salmonellae among inmates of this 1 institution, careful study was made of the stools of the 11 men who had volunteered for the experiment. Repeated cultures of the stools of the 2 men with bacteremia failed to demonstrate any pathogenic bacteria. Cultures of the stools of the other 3 volunteers who had contracted hepatitis experimentally, as well as the 6 who had not sickened, were also negative.

A similar experiment with 8 human volunteers was being conducted simultaneously in another institution with an agent of homologous serum jaundice. The incidence of dysentery and infections due to salmonellae in this institution was low. Culture of the stools of the 8 volunteers in this experiment, including 3 who contracted homologous serum jaundice experimentally, were also negative for pathogenic bacteria.

During the past few months a study was made of the stools of 15 additional human volunteers who contracted virus-induced infectious hepatitis experimentally. No pathogenic bacteria were found. The incidence of infection due to the dysentery-salmonella groups of organisms was low in the institutions where these men lived and worked.

\section{SEROLOGICAL STUDIES}

The strains of $S$. choleraesuis which were isolated from the 2 patients ML and RN were of the Kunzendorf variety. ${ }^{8}$ They were agglutinated in a titre of $1: 2560$ and $1: 5180$ respectively by commercial anti-serum of $S$. schottmuelleri. No agglutination occurred when either strain was exposed to anti-serum of $B$. typhosus or $S$. paratyphi. Each of these 2 patients developed during the course of the disease a significant rise in titre of agglutinins to his own strain and also to the other patient's strain of $S$. choleraesuis. Similar increase in agglutinating titre, although of a lesser order, was observed when the sera of these 2 patients were tested against a swine strain and another human strain of $S$. choleraesuis. No significant amount of agglutinins was detected in either of these sera for 2 strains of $S$. schottmuelleri, $S$. paratyphi, or B. typhosus. The other 21 volunteers who contracted hepatitis were also studied in relation to their serological reactions to several strains of salmonellae. These results are recorded in Table II. All of these volunteers had been vaccinated against typhoid and paratyphoid fever within periods ranging from 5 to 23 months before the onset of disease.

One patient (volunteer $\mathrm{ON}$ ) had moderate rise in titre of agglutinins to 3 strains of salmonellae. Cultures of the blood were sterile, and cultures of the stool and urine revealed no pathogenic bacteria. He had been vaccinated against typhoid and paratyphoid fever approximately 10 months before infection and was resident in an institution in which the incidence of infection due to the salmonella-dysentery groups of organisms was low.

${ }^{3}$ Identified by Dr. P. R. Edwards, Kentucky Agricultural Experiment Station, Lexington, Kentucky. 
TABLE II

Maximum titers of agglutinins against 7 strains of paratyphoid and typhoid bacilli in the sera of volunteers with virus induced experimental hepatitis

\begin{tabular}{|c|c|c|c|c|c|c|c|c|c|}
\hline \multirow{2}{*}{ Volunteer } & \multirow{2}{*}{ Bacteremia } & \multirow{2}{*}{$\begin{array}{l}\text { Day of } \\
\text { disease }\end{array}$} & \multicolumn{3}{|c|}{ S. choleraesuis } & \multicolumn{2}{|c|}{ S. schottmuelleri } & \multirow{2}{*}{$\begin{array}{l}S \text {. paratyphi } \\
\text { Hartford }\end{array}$} & \multirow{2}{*}{$\begin{array}{l}\text { B. typhosus } \\
\text { Hartford }\end{array}$} \\
\hline & & & Edwards & Swine & Mundell & Hartford & Thompson & & \\
\hline $\mathrm{RN}$ & + & $\begin{array}{r}5 \\
24 \\
31\end{array}$ & $\begin{array}{r}15 \\
240\end{array}$ & $\begin{array}{r}15 \\
240\end{array}$ & $\begin{array}{r}60 \\
960 \\
640\end{array}$ & $\begin{array}{l}60 \\
30\end{array}$ & $\begin{array}{l}30 \\
30\end{array}$ & $\begin{array}{l}\mathbf{0} \\
\mathbf{0}\end{array}$ & $\begin{array}{l}15 \\
20\end{array}$ \\
\hline ML & + & $\begin{array}{l}14 \\
23 \\
30\end{array}$ & 460 & 120 & $\begin{array}{r}0 \\
460 \\
160\end{array}$ & $\begin{array}{l}20 \\
30\end{array}$ & 15 & $\begin{array}{r}160 \\
0\end{array}$ & $\begin{array}{r}80 \\
120\end{array}$ \\
\hline ON & - & $\begin{array}{r}* \\
10 \\
32\end{array}$ & $\begin{array}{r}30 \\
120 \\
240\end{array}$ & $\begin{array}{r}120 \\
0 \\
60\end{array}$ & $\begin{array}{r}15 \\
0 \\
15\end{array}$ & $\begin{array}{r}60 \\
480 \\
480\end{array}$ & $\begin{array}{r}15 \\
960 \\
480\end{array}$ & $\begin{array}{r}60 \\
0 \\
0\end{array}$ & $\begin{array}{l}240 \\
120 \\
480\end{array}$ \\
\hline $\begin{array}{l}\text { BD } \\
\text { BK } \\
\text { GR } \\
\text { HU } \\
\text { JO } \\
\text { KRL } \\
\text { LN } \\
\text { LG } \\
\text { JE } \\
\text { MA } \\
\text { MN } \\
\text { KH } \\
\text { KL } \\
\text { PK } \\
\text { SN } \\
\text { WE } \\
\text { ZI } \\
\text { HS } \\
\text { JS } \\
\text { MS }\end{array}$ & $\begin{array}{l}= \\
\bar{z} \\
= \\
= \\
= \\
= \\
= \\
= \\
= \\
= \\
= \\
=\end{array}$ & $\begin{array}{l}19 \\
15 \\
20 \\
15 \\
15 \\
23 \\
16 \\
14 \\
23 \\
14 \\
19 \\
15 \\
21 \\
15 \\
20 \\
14 \\
18 \\
21 \\
21 \\
25\end{array}$ & $\begin{array}{r}0 \\
0 \\
0 \\
30 \\
30 \\
15 \\
0 \\
0 \\
15 \\
0 \\
0 \\
0 \\
0 \\
0 \\
0 \\
30 \\
30 \\
0 \\
0 \\
15\end{array}$ & $\begin{array}{r}0 \\
15 \\
0 \\
30 \\
0 \\
0 \\
0 \\
0 \\
0 \\
0 \\
0 \\
0 \\
0 \\
0 \\
0 \\
15 \\
15 \\
0 \\
0 \\
0\end{array}$ & $\begin{array}{r}0 \\
0 \\
0 \\
0 \\
0 \\
0 \\
0 \\
0 \\
0 \\
0 \\
0 \\
15 \\
0 \\
0 \\
0 \\
30 \\
15 \\
0 \\
0 \\
0\end{array}$ & $\begin{array}{r}0 \\
0 \\
15 \\
0 \\
60 \\
0 \\
0 \\
30 \\
0 \\
15 \\
15 \\
0 \\
0 \\
30 \\
30 \\
120 \\
120 \\
0 \\
0 \\
30\end{array}$ & $\begin{array}{r}0 \\
0 \\
15 \\
0 \\
60 \\
60 \\
30 \\
15 \\
0 \\
30 \\
0 \\
0 \\
0 \\
0 \\
0 \\
15 \\
15 \\
0 \\
0 \\
0\end{array}$ & $\begin{array}{r}15 \\
0 \\
0 \\
0 \\
0 \\
0 \\
120 \\
0 \\
0 \\
15 \\
0 \\
15 \\
0 \\
0 \\
0 \\
30 \\
0 \\
15 \\
0\end{array}$ & $\begin{array}{r}0 \\
240 \\
30 \\
0 \\
240 \\
60 \\
120 \\
240 \\
0 \\
0 \\
0 \\
15 \\
15 \\
0 \\
0 \\
120 \\
120 \\
240 \\
30 \\
0 \\
0\end{array}$ \\
\hline
\end{tabular}

* Before onset.

\section{METHOD USED IN SEROLOGICAL STUDIES}

Source of strains. Seven strains of enteric bacilli were employed. Three strains, namely, S. paratyphi, S. schottmuelleri (Hartford), and $B$. typhosus, were obtained from Dr. F. L. Mickle of the Bureau of Laboratories, State Department of Health, Hartford, Connecticut. Two other strains of $S$. choleraesuis var. Kunzendorf, one of human and the other of swine origin, were supplied by Dr. P. R. Edwards, of the Kentucky Agricultural Experiment Station, Lexington, Kentucky. One of our strains of $S$. choleraesuis var. Kunzendorf (Mundell) isolated from volunteer ML, and a strain of $S$. schottmuelleri (Thompson) isolated from an inmate in the institution where volunteer ML worked, were employed in these tests also.

Preparation of antigens. Broth cultures of smooth motile strains were seeded on beef heart infusion agar flasks and incubated for 18 to 24 hours. The growth of each organism was harvested from each flask and suspended in 0.9 per cent saline. The antigen was subcultured, and tested for purity before use in the agglutination tests.

Sera. Acute and convalescent phase sera were obtained from each volunteer during the first and third week after the onset of experimental hepatitis. Sera were frozen and stored at dry-ice box temperature for periods ranging from 2 to 4 months and were thawed at room temperature on the day of the test. If a significant rise in titre of agglutinins to any of the 7 antigens was encountered, serial specimens of serum which had been obtained during the course of hepatitis in each volunteer and kept frozen at dry-ice box temperature were tested. In Table II, the results of 3 such patients are recorded. Of the other 20 patients who had no significant increase in titre of agglutinins to the antigens tested, only the results of testing the serum obtained in the third week (convalescent) of disease are recorded.

Technique. Serial two-fold dilutions of serum in dilution $1: 15$ to $1: 3840$ were prepared in $0.5 \mathrm{ml}$. of sterile normal ( 0.85 per cent) saline. The strains of organisms employed in the test were diluted to number 3 standard on the McFarland nephelometric scale, and $0.5 \mathrm{ml}$. added to each tube in series. The tubes were then incubated at $56^{\circ} \mathrm{C}$. for 2 hours, stored at $+6^{\circ} \mathrm{C}$. overnight, and the results recorded on the following morning. The final dilution showing agglutination visable to the eye was considered the end-point of agglutinin titre. 
For control purposes, commercial antisera against $S$. paratyphi, $S$. schottmuelleri, and $B$. typhosus, prepared by Lederle \& Co., were employed to detect loss of agglutinability of antigens.

\section{DISCUSSION}

It has been pointed out in this paper that the occurrence of bacteremia due to various strains of salmonellae (usually $S$. paratyphi and $S$. schottmuelleri) in patients with epidemic jaundice was interpreted in "pre-virus" days of 25 years ago as indicating that paratyphoid bacilli might cause epidemic jaundice. This concept was subsequently abandoned, and the concept of virus etiology of infections hepatitis has been more recently established when the disease was found to be readily reproducible by feeding or injecting human volunteers with a filtrable agent. That 2 of the volunteers who became infected experimentally with the virus should also develop bacteremia with $S$. choleraesuis during the course of virus-induced experimental hepatitis, is, we believe, a highly significant fact, particularly as this occurred only among volunteers who lived and worked in an institution where infections due to the salmonelladysentery groups of organisms had been endemic in fair proportion. This occurrence is important as a possible indication that a virus infection of the human intestinal tract may be complicated by a superimposed bacterial infection. As such, it is reminiscent of the situation in hog cholera, in which $S$. choleraesuis frequently becomes active as a secondary invader of the intestinal tract of the hog primarily damaged by a filrable virus (29). The fact that 20 other volunteers with experimental hepatitis, most of them located in other institutions where the rate of infections due to salmonellae was low, showed no evidence serologically or by culture of relationship with any 1 of 6 strains of salmonellae, lends support to this view. The 1 volunteer with experimental infectious hepatitis who did show a moderate rise in titre of agglutinins to 3 strains of salmonellae had been vaccinated 10 months previously, and it is likely that his response represented an anamnestic reaction. Reference to this possibility has been made by Nichols (30) who observed a similar moderate rise in titre of agglutinins in 6 out of 22 patients previously vaccinated against salmonellae.

\section{SUMMARY AND CONCLUSIONS}

1. Hepatitis has been transmitted experimentally to 23 human volunteers by the oral or parenteral administration of a filtrable agent. During the course of their hepatitis, 2 of these men, who worked and lived in an institution where infections due to salmonellae were endemic in fair proportion, developed a superimposed bacteremia ( $S$. choleraesuis).

2. Serologic study of these 23 patients showed appropriate evidence of bacterial infection in the 2 subjects who had bacteremia during the course of experimental hepatitis, while the other volunteers (with 1 exception) failed to show any serologic response to several strains of salmonellae.

3. The occurrence of bacteremia with $S$. choleraesuis during the course of virus-induced experimental hepatitis in 2 human volunteers offers suggestive evidence that a virus infection of the human intestinal tract may render it more susceptible to bacterial infection.

4. Experimental evidence that the etiologic agent of infectious hepatitis is filtrable and may be transmitted to man by the intestinal-oral routes suggests that the previous association of paratyphoid bacilli with infectious hepatitis, observed so frequently in the first World War constituted a double infection made possible, in part, by unsanitary conditions which favored the spread of both diseases.

Acknowledgments for assistance received are due to Dr. S. F. Price, U.S.P.H.S. and Miss Helen Wand.

Acknowledgment is made of the assistance and cooperation of the following agencies: Selective Service, Camp Operations Division; Civilian Public Service Unit No. 68; Civilian Public Service Unit No. 81; Civilian Public Service Unit No. 140; the Norwich State Hospital, Norwich, Connecticut; the Connecticut State Hospital, Middletown, Connecticut; and the Federal Correctional Institution, Danbury, Connecticut.

\section{BIBLIOGRAPHY}

1. Voegt, H., Zur aetiologie der hepatitis epidemica. München Med. Wchnschr., 1942, 89, 76. Abstr. Bull. Hyg., 1942, 17, 331.

2. Cameron, J. D. S., Infective hepatitis. Quart. J. Med., 1943, 12, 139.

3. MacCallum, F. O., and Bradley, W. H., Transmission of infective hepatitis to human volunteers. Lancet, 1944, 2, 228. 
4. Havens, W. P., Jr., Ward, R., Drill, V. A., and Paul, J. R., Experimental production of hepatitis by feeding icterogenic materials. Proc. Soc. Exper. Biol. and Med., 1944, 57, 206.

5. Havens, W. P., Jr., Paul, J. R., and van Rooyen, C. E., Human transmission of infective hepatitis by the oral route. Lancet, 1945, 1, 202.

6. Findlay, G. M., and Wilcox, R. R., Transmission of infectious hepatitis by faeces and urine. Lancet, 1945, 1, 212.

7. Havens, W. P., Jr., Properties of the etiologic agent of infectious hepatitis. Proc. Soc. Exper. Biol. and Med., 1945, 58, 203.

8. Blumer, G., Infectious jaundice in the United States. J.A.M.A., 1923, 81, 353.

9. Molner, J. G., and Kasper, J. A., An outbreak of jaundice in Detroit. J.A.M.A., 1938, 110, 2069.

10. Norton, J. A., Acute infectious jaundice. J.A.M.A., $1939,113,916$.

11. Ford, J. C., Infective hepatitis (epidemic catarrhal jaundice): Three hundred cases in an outer London borough. Lancet, 1943, 1, 675.

12. Carnot, P., and Weile-Halle, B., Etude clinique et bacteriologique d'une petite épidémie d'ictère infectieux. Bull. et Mém. Soc. Méd. d. hôp de Paris, 1915, 39, (3s), 377.

13. Barker, L. F., and Sladen, F. J., A small epidemic of jaundice with symptoms of gastro-intestinal catarrh. Bull. Johns Hopkins Hosp., 1909, 20, 310.

14. Lippman, A., Zur pathogenese des "icterus catarrhalis." Med. Klin., Berl., 1922, 18, 1176.

15. Anigstein, L., and Milinska, Z., Investigations of jaundice of bacterial origin. J. Trop. Med. and Hyg., London, 1923, 26, 337.

16. Cantacuzène, J., Sur une épidémie d'ictère observée en Roumanie. La Presse Médicale, 1918, 26, 541.

17. Sarrailhé, A., and Clunet, J., La "jaunisse des camps" et l'épidémie de paratyphoide des Dardanelles.
Bull. et Mém. Soc. Méd. d. hôp de Paris, 1916, 40, (3s), 45.

18. Hurst, A. F., Infective jaundice at Gallipoli. Brit. M. J., 1917, 1, 527.

19. Wilcox, W. H., Jaundice, with special reference to types occurring during the war. Brit. M. J., 1919, $1,639$.

20. Wilcox, W. H., The epidemic jaundice of campaigns. Brit. M. J., 1916, 1, 297.

21. Martin, C. J., Concerning the pathology and etiology of the infectious jaundice common at the Dardanelles, 1915. Brit. M. J., 1917, 1, 445.

22. Brugsch, T., and Shürer, J., Ueber gutartige epidemishe gelbsucht. Berl. Klin. Wchnschr., 1919, 56, 601.

23. Garnier, M., and Reilly, J., Conception nosologique des ictères typhoparatyphique. Paris Méd., 1923, 50, 229.

24. Costa, S., and Troisier, J., Deux épidémies d'ictère commun. Annales de Méd., 1924, 16, 180.

25. Jaundice at Alexandria. Edit., Brit. M. J., 1916, 1, 320.

26. Havens, W. P., Jr., Experiment in cross immunity between infectious hepatitis and homologous serum jaundice. Proc. Soc. Exper. Biol. and Med., 1945, 59, 148.

27. Unpublished observations of one of the authors (WPH, Jr.).

28. Paul, J. R., Havens, W. P., Jr., Sabin, A. B., and Philip, C. B., Transmission experiments in serum jaundice and infectious hepatitis. J.A.M.A., 1945, 128, 911.

29. Hutyra, F., and Marek, J., Special Pathology and Therapeutics of the Diseases of Domestic Animals. London, Baillière, Tindall, and Cox, 1926, p. 322.

30. Nichols, H. J., Agglutination of typhoid group of organisms in cases of jaundice among vaccinated persons. J.A.M.A., 1923, 81, 1946. 